\title{
Detecting animal by-product intake using stable isotope ratio mass spectrometry (IRMS)
}

\author{
D.A.F. da Silva a,b, N.P. Biscola ${ }^{\text {a,b }}$, L.D. dos Santos ${ }^{\text {a,b }}$, M.M.P. Sartori ${ }^{c}$, J.C. Denadai ${ }^{\mathrm{d}}$, \\ E.T. da Silva ${ }^{\mathrm{d}}$, C. Ducatti ${ }^{\mathrm{d}}$, S.D. Bicudo ${ }^{\mathrm{e}}$, B. Barraviera ${ }^{\mathrm{a}, \mathrm{b}}$, R.S. Ferreira Jr. ${ }^{\mathrm{a}, \mathrm{b}, *}$ \\ ${ }^{a}$ Center for the Study of Venoms and Venomous Animals (CEVAP), UNESP - Univ Estadual Paulista, Botucatu, SP, Brazil \\ b Botucatu Medical School, UNESP - Univ Estadual Paulista, Botucatu, SP, Brazil \\ ' College of Agricultural Sciences, UNESP - Univ Estadual Paulista, Botucatu, SP, Brazil \\ d Stable Isotopes Center (CIE), UNESP - Univ Estadual Paulista, Botucatu, SP, Brazil \\ e College of Veterinary Medicine and Animal Husbandry (FMVZ), UNESP - Univ Estadual Paulista, Botucatu, SP, Brazil
}

\section{A R T I C L E I N F O}

Article history:

Accepted 4 October 2016

\section{Keywords:}

Animal by-product intake

Stable isotopes

$\delta^{13} \mathrm{C}$ value

$\delta^{15} \mathrm{~N}$ value

Sheep

\begin{abstract}
A B S T R A C T
Sheep are used in many countries as food and for manufacturing bioproducts. However, when these animals consume animal by-products (ABP), which is widely prohibited, there is a risk of transmitting scrapie a fatal prion disease in human beings. Therefore, it is essential to develop sensitive methods to detect previous ABP intake to select safe animals for producing biopharmaceuticals. We used stable isotope ratio mass spectrometry (IRMS) for ${ }^{13} \mathrm{C}$ and ${ }^{15} \mathrm{~N}$ to trace animal proteins in the serum of three groups of sheep: 1 - received only vegetable protein (VP) for 89 days; 2 - received animal and vegetable protein (AVP); and 3 - received animal and vegetable protein with animal protein subsequently removed (AVPR). Groups 2 and 3 received diets with 30\% bovine meat and bone meal (MBM) added to a vegetable diet (from days 16-89 in the AVP group and until day 49 in the AVPR group, when MBM was removed).

The AVPR group showed ${ }^{15} \mathrm{~N}$ equilibrium 5 days after MBM removal (54th day). Conversely, ${ }^{15} \mathrm{~N}$ equilibrium in the AVP group occurred 22 days later (76th day). The half-life differed between these groups by 3.55 days. In the AVPR group, ${ }^{15} \mathrm{~N}$ elimination required 53 days, which was similar to this isotope's incorporation time. Turnover was determined based on natural ${ }^{15} \mathrm{~N}$ signatures. IRMS followed by turnover calculations was used to evaluate the time period for the incorporation and elimination of animal protein in sheep serum. The $\delta^{13} \mathrm{C}$ and $\delta^{15} \mathrm{~N}$ values were used to track animal protein in the diet. This method is biologically and economically relevant for the veterinary field because it can track protein over time or make a point assessment of animal feed with high sensitivity and resolution, providing a low-cost analysis coupled with fast detection. Isotopic profiles could be measured throughout the experimental period, demonstrating the potential to use the method for traceability and certification assessments.
\end{abstract}

(c) 2016 Elsevier Ltd. All rights reserved.

\section{Introduction}

Globally, ruminants, especially cattle, buffaloes, goats and sheep, are responsible for the production of $30 \%$ of the meat and $100 \%$ of the milk available for human consumption. ${ }^{1}$ In addition, sheep, cattle and buffaloes are still used for the production of biopharmaceuticals (Peres et al., 2006; Barros et al., 2009; Lavonas et al., 2011; Ferreira, 2014; Abbade et al., 2015).

\footnotetext{
* Corresponding author.

E-mail address: rseabra@cevap.unesp.br (R.S. Ferreira Jr.).

1 See: Alexandratos, N., Bruinsma, J. 2012. World Agriculture Towards 2030/ 2050. The 2012 revision. Rome, June 2012. ESA Working Paper No. 12-03. http://www.fao.org/docrep/016/ap106e/ap106e.pdf (accessed 28 September 2016).
}

Sheep are an important part of the global agricultural economy and their biological products are of interest for manufacturing bioproducts such as antivenoms (Peres et al., 2006; Lavonas et al., 2011). However, these products may pose risks to human health because of the possible transmission of spongiform encephalopathies (TSEs), also termed prion diseases (PDs), which can be transmitted via the intake of animal by-product proteins (ABPs; Bencsik and Baron, 2011; Marruchella et al., 2012). PDs include scrapie in sheep, bovine spongiform encephalopathy (BSE) in bovines and Creutzfeldt-Jakob disease (CJD) in humans (Thackray et al., 2011). However, in sheep there is more than one form of prion; there are numerous strains with different pathological and biochemical characteristics that may affect animals differently depending on their genotypes (Leal et al., 2015).

Significantly, a new CJD variation has been etiologically linked to exposure to BSE and scrapie agents through the food chain (Bruce 
et al., 1997; Ironside, 1998). Epidemiological studies have failed to identify specific risk factors for the disease other than the consumption of ABPs. However, experiments have demonstrated the transmission of BSE and scrapie via blood transfusions (Hunter et al., 2002; Houston et al., 2008). Cassard et al. (2014) demonstrated that scrapie prions have a zoonotic potential, raising new questions about the possible link between animal and human prions in mouse models.

The addition of ABPs to ruminant feed is prohibited in most countries due to the risk of PD transmission. 2,3,4 Thus, monitoring PDs in ruminants is crucial and depends on accurate diagnoses. This unique challenge requires the development of novel assays to explore prion protein complexes (Sobrova et al., 2012). Currently diagnostic tests for PDs can only be performed when animals show symptoms or postmortem (Leal et al., 2015; Cosier and Daraban, 2016).

In most cases where PDs are detected, the entire herd is sacrificed, causing great harm to the producers and the country by preventing them from exporting their products. Therefore, the search for accurate methods to detect previous animal protein intake is essential because it can show how and where the animals were raised, if there is a risk for human consumption and, finally, can select animals suitable for the pharmaceutical industry.

Stable isotope ratio mass spectrometry (IRMS) has recently been proposed as a tool for authenticating animal products (Bahar et al., 2008; Chesson et al., 2008; Heaton et al., 2008), certifying the geographic origin and types of sheep feed (Piasentier et al., 2003) and evaluating conventional and organic production systems for beef (Schmidt et al., 2005). The analysis of biological samples using this technique may reflect the animal proteins in diets (Denadai et al., 2008; Cruz et al., 2012). However, there is a gap between the approach used to trace proteins and assessments of their tissue turnover rates (Bahar et al., 2009). Ascertaining the assimilation of stable isotopes in different tissues or biological fluids can define turnover rates, which depend on feeding times (Fossato da Silva et al., 2012; Martinez et al., 2014).

Using naturally occurring stable isotopes as dietary indicators can provide information about diets over both short- and longterm periods, depending on the type of tissue evaluated. However, to obtain such information, studies on the isotopic assimilation of organic matter in different animal tissues need to be carried out (Martins et al., 2012). There are few descriptions of turnover in biological samples and/or tissues from sheep, and they are focused on turnover involving $C_{3}$ and $C_{4}$ plant diets (Zazzo et al., 2008; Harrison et al., 2011; Martins et al., 2012) and lipid metabolism studies (Hattori et al., 2010; Richter et al., 2012).

A theoretical model to express the relative isotopic enrichment $(\delta \mathrm{x})$ using carbon-13 $\left(\delta^{13} \mathrm{C}\right)$ was proposed by Tieszen et al. (1983). The hypothesis is based on the metabolism of certain animal tissues, which depends on the input rate of dietary carbon compounds and the substitution rate of the preexisting compounds. This model provides parameters such as the half-life $(T)$ and turnover rate $(k)$,

\footnotetext{
2 See: European Commission Food Safety, 2001. Use of processed animal proteins in animal feed. http://ec.europa.eu/food/fs/bse/bse28_en.html (accessed 28 September 2016).

3 See: MAPA (Ministério da Agricultura, Pecuária e Abastecimento), 2004. Instrução Normativa 8/2004. Diário oficial de 26 de março de 2004 da República Federativa do Brasil, Brasília, Seção 1, página 5. http://sistemasweb.agricultura.gov.br/sislegis/ action/detalhaAto.do? method=visualizarAtoPortalMapa\&chave=178957228 (accessed 28 September 2016).

4 See: US Government Publishing Office, 2016. Electronic Code of Federal Regulations. Part 589 - Substances prohibited from use in animal food or feed. http://www.ecfr.gov/cgi-bin/text-idx?SID=d39395bd805dd6dfc837d2a79ae27a18\&mc $=$ true $\&$ node $=$ pt21.6.589\&rgn=div5 (accessed 28 September 2016).
}

allowing the substitution time for the incorporation of a diet to be ascertained.

Therefore, the aim of this study was to detect previous ABP intake by determining the stable isotope ratios for carbon $\left({ }^{13} \mathrm{C} /{ }^{12} \mathrm{C}\right)$ and nitrogen $\left({ }^{15} \mathrm{~N} /{ }^{14} \mathrm{~N}\right)$ in sheep serum.

\section{Materials and methods}

Animals

This study was conducted in accordance with the Ethical Principles in Animal Research of the Brazilian College of Animal Experimentation and was approved by the Ethics Committee for Animal Experimentation (Protocol $N^{\circ} 78$; August 2009) of the College of Veterinary Medicine and Animal Husbandry (FMVZ), Univ Estadual Paulista (UNESP), Brazil. The welfare of animals was respected throughout the experimental period by following the 'five freedoms' in accordance with the Farm Animal Welfare Council.

At the end of the experiment, the animals in the animal and vegetable protein (AVP) and the animal and vegetable protein removal (AVPR) groups were euthanized as described by the Ministry of Agriculture, Livestock and Supply, ${ }^{3}$ Brazilian Government Legislation. The control group (vegetable protein, VP) was released for use in other studies.

\section{Animals and experimental design}

Twenty-three Santa Ines sheep, aged 150 days and weighing approximately $35 \mathrm{~kg}$, were fed a vegetable-based diet for 15 days to measure ${ }^{13} \mathrm{C}$ and ${ }^{15} \mathrm{~N}$ isotopic homogenization values. All the animals were fed the mineral supplement CONNAN $\left(\mathrm{Ca}^{++}\right.$, $140 \mathrm{mg} / \mathrm{g} ; \mathrm{Na}^{+}, 133 \mathrm{mg} / \mathrm{g} ; \mathrm{P}--, 80 \mathrm{mg} / \mathrm{g} ; \mathrm{S}^{--}, 12 \mathrm{mg} / \mathrm{g} ; \mathrm{Mg}^{++}, 7 \mathrm{mg} / \mathrm{g} ; \mathrm{Zn}^{++}, 4200 \mathrm{mg} /$ g; $\mathrm{Fe}^{++}, 1.500 \mathrm{mg} / \mathrm{g} ; \mathrm{F}^{-} 800, \mathrm{mg} / \mathrm{g} ; \mathrm{Mn}^{++}, 800 \mathrm{mg} / \mathrm{g} ; \mathrm{Cu}^{++}, 300 \mathrm{mg} / \mathrm{g} ; \mathrm{I}^{-}, 150 \mathrm{mg} / \mathrm{g} ; \mathrm{Co}^{++}$, $100 \mathrm{mg} / \mathrm{g}$; $\mathrm{Se}^{++}, 15 \mathrm{mg} / \mathrm{g}$; and flavoring $5 \mathrm{mg} / \mathrm{g}$ ).

Next, the animals were divided into three experimental groups: one control group (VP; $n=7$ ), which continued with the starter diet (vegetable-based diet only) for the 89 days of the experiment (days 0-89), and two treated groups (AVP and AVPR; $n=8$ / group) that were fed diets with $30 \%$ bovine meat and bone meal (MBM; Mondelli commercial feed - humidity, $8 \%$; crude protein, $45 \%$ and ether extract, $6 \%$ ) added to vegetable diet from the 16th day. The AVP group continued on this diet until the 89th day (16-89 days). The AVPR group was fed this diet until the 49th day (16-49 days), when the MBM was removed.

All the animals were microchipped and received Coast-cross hay (88.96\% dry matter with $92.12 \%$ organic matter, $11.45 \%$ crude protein, $1.75 \%$ ether extract, $30.76 \%$ crude fiber, $48.16 \%$ nitrogen-free extract, and $7.88 \%$ ash) and water ad libitum throughout the experimental period.

Serum preparation and measurement of $\delta^{13} \mathrm{C}$ and $\delta^{15} \mathrm{~N}$ using stable isotope-ratio mass spectrometry (IRMS)

Blood samples were taken from the animals' jugular veins twice per week (at 08:00-10:00 a.m.) and collected in $10 \mathrm{~mL}$ Vacutainer ${ }^{\circledR}$ tubes, in which the samples were centrifuged at $2500 \mathrm{rpm}$ for $30 \mathrm{~min}$ at $4{ }^{\circ} \mathrm{C}$. Then, $1 \mathrm{~mL}$ of serum was lyophilized and stored in microtubes at $-20^{\circ} \mathrm{C}$. Approximately 50-70 $\mu \mathrm{g}$ and $500-600 \mu \mathrm{g}$ of lyophilized serum were weighed and placed in tin capsules to analyze ${ }^{13} \mathrm{C}$ and ${ }^{15} \mathrm{~N}$, respectively. Afterwards, the capsules were stored in ELISA microplates and maintained at $4{ }^{\circ} \mathrm{C}$ until the isotopic analysis.

The ${ }^{13} \mathrm{C} /{ }^{12} \mathrm{C}$ and ${ }^{15} \mathrm{~N} /{ }^{14} \mathrm{~N}$ ratios were measured in a Delta $\mathrm{V}$ Advantage Isotope Ratio Mass Spectrometer (Thermo Scientific). The isotopic ratios are expressed as delta per thousand $(\delta)$ relative to the international standards Pee Dee Belemnite (PDB) for ${ }^{13} \mathrm{C}$ and atmospheric nitrogen for ${ }^{15} \mathrm{~N}$, according to equation (1) (Tieszen et al., 1983; Martinez et al., 2014).

$\delta_{\text {(sample,standard })}=\left(\frac{\mathrm{R}_{\text {sample }}-\mathrm{R}_{\text {standard }}}{\mathrm{R}_{\text {standard }}}\right)$

$\mathrm{R}$ represents the ratio between the least and the most abundant isotope, specifically ${ }^{13} \mathrm{C} /{ }^{12} \mathrm{C}$ and ${ }^{15} \mathrm{~N} /{ }^{14} \mathrm{~N}$, and $\delta$ represents the relative isotopic enrichment.

\section{Turnover evaluation}

To quantitatively measure the speed of isotope replacement (turnover) after determining the time interval, the first order exponential function was used, as expressed in equation (2) (Tieszen et al., 1983; Martinez et al., 2014).

$\delta \mathrm{x}_{(\mathrm{t})}=\delta \mathrm{x}_{(\mathrm{f})}+\left(\delta \mathrm{x}_{(\mathrm{i})}-\delta \mathrm{x}_{(\mathrm{f})}\right) \mathrm{e}^{-\mathrm{kt}}$

where 
$\delta \mathrm{x}(\mathrm{t})=$ isotopic enrichment of the tissue at any time $(\mathrm{t})$;

$\delta \mathrm{x}(\mathrm{f})=$ isotopic enrichment of the tissue under the final condition, isotopic equilibrium;

$\delta \mathrm{x}(\mathrm{i})=$ isotopic enrichment of the tissue under the initial condition;

$\mathrm{k}=$ change constant (turnover) in time;

$\mathrm{t}=$ time (in days) since feed was replaced.

To determine the total exchange time for isotope atoms (99\%) in the serum, equation (3) was used (Hobson, 1999; Cerling et al., 2007).

$\mathrm{t}=\left(-\frac{1}{\mathrm{k}}\right) \ln (1-\mathrm{F})$

$\mathrm{F}$ is the variable that represents the fraction approaching equilibrium, which ranges from zero to one (fraction of exchanged atoms), and ( $t$ ) is the elapsed time for any value of $\mathrm{F}$, given the parameter (k). For example, if half of the atoms in a tissue have been exchanged $(F=0.5)$, the known half-life $(T)$ expression can be determined.

Traceability

The resulting $\delta^{13} \mathrm{C}$ and $\delta^{15} \mathrm{~N}$ values were plotted in a scatter diagram, which allows for the evaluation of the relationship of these two isotopes and of differences in this relationship in the diets with and without the addition of animal protein.

\section{Statistical methods}

After the polynomial fit was obtained, the maximum value of the first-order exponential function was evaluated to define the period for isotopic incorporation in the sera of the AVPR group, a setting that emphasized the equilibration in the AVPR group. Data from the AVP and AVPR groups were adjusted base on a nonlinear regression curve (first-order exponential function) according to equation (2). The VP group was adjusted using a linear regression with Minitab 16 (Minitab16 Statistical Software). Then, $\mathrm{k}$ and $\mathrm{T}$ values were determined. The adaptation period (0-15 days) was excluded from this analysis for all groups.

ANOVAs and Tukey's tests $(P<0.05)$ were used to evaluate the average $\delta^{15} \mathrm{~N}$ and $\delta^{13} \mathrm{C}$ values from different periods.

\section{Results}

To determine whether the ${ }^{12} \mathrm{C} /{ }^{13} \mathrm{C}$ and ${ }^{14} \mathrm{~N} /{ }^{15} \mathrm{~N}$ ratios in sheep changed following dietary changes, these ratios were analyzed in three groups: one that was fed a base diet consisting of vegetable protein only (VP) for the 89 days of the experiment (days 0-89); one that was fed a diet with $30 \%$ bovine meat and bone meal added between days 16 and 89 (AVP); and one that was fed 30\% bovine meat and bone meal between days 16 and 49 (AVPR).

There was no variation in ${ }^{13} \mathrm{C}$ isotope levels across all sample collection dates or among the experimental groups (Fig. 1); thus, turnover rates could not be estimated. In contrast, ${ }^{15} \mathrm{~N}$ incorporation increased following the inclusion of MBM in the diet and to decrease again following the removal of MBM from the diet, as shown by the results from the AVPR group (Fig. 2). For this group, a first-order polynomial fit identified a maximum ${ }^{15} \mathrm{~N}$ abundance at 54 days, 5 days after the MBM has been removed (Fig. 2), resulting in a 39-day period of net ${ }^{15} \mathrm{~N}$ incorporation in the AVPR group.

Thus, in regard to isotopic equilibrium, $99 \%$ of the ${ }^{15} \mathrm{~N}$ atoms in the AVP group and 95\% in the AVPR group were exchanged (Fig. 3). The 39-day period indicated that equilibrium had been reached; i.e., $97 \%$ and $99 \%$ of the animal's cells had substitution of nitrogen atoms (Fig. 3); therefore the trial period was sufficient for complete incorporation of the diets containing animal protein. The values of $97 \%$ and $99 \%$ for exchanged atoms (F\%) were calculated using equation (3) to determine the F value for each study group individually, using $\mathrm{t}=74$ days for the AVPR group and $\mathrm{t}=39$ days for the AVP group (Fig. 3).

Using the turnover model for the AVPR and AVP groups produced the equations $\delta^{15} \mathrm{~N}(\mathrm{t})=9.49-1.86 \mathrm{e}^{-0.0878 \mathrm{t}}$, with $r^{2}=0.90$, and $\mathrm{T}=7.89$ days; and $\delta^{15} \mathrm{~N}(\mathrm{t})=9.80-1.81 \mathrm{e}^{-0.0606 \mathrm{t}}$, with $r^{2}=0.62$, and $\mathrm{T}=11.44$ days, respectively. The half-life values differed between these groups by only $\mathrm{T}=3.55$ days, demonstrating that $50 \%$ of the nitrogen atoms had been substituted in the cells. Isotopic equilib-

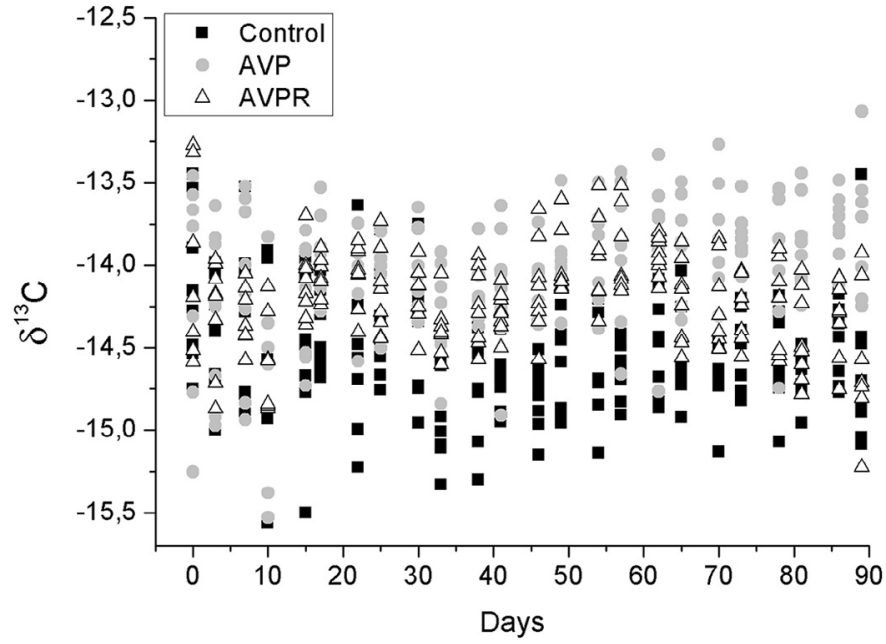

Fig. 1. $\delta^{13} \mathrm{C}$ values determined from serum collected at different time points within the trial period showing no significant changes for any of the animal groups. Control animals did not receive any animal by-products in their feed, the AVP group received 30\% bovine meat and bone meal from day 16 until the end of the trial, and the AVPR group received 30\% bovine and bone meal between days 16 and 49 of the trial.

rium was confirmed in this experiment, which minimized the errors in the half-life calculations.

In the first days after animal protein incorporation in the diet, serum ${ }^{15} \mathrm{~N}$ isotope enrichment in the AVPR and AVP groups was different from that in the control group. There was no ${ }^{15} \mathrm{~N}$ enrichment in the serum samples of the control sheep, demonstrating that their diet was exclusively vegetable-based (Fig. 3).

Although the experiment evaluated the animals only up to 35 days (Fig. 4) after the removal of animal proteins from the diet, the total reversibility of the ${ }^{15} \mathrm{~N}$ isotopic value in the AVPR group was mathematically estimated to have occurred at 53 days based on the equation:

$\delta^{15} \mathrm{~N}(\mathrm{t})=8.35-1.28 \mathrm{e}^{-0.08726 \mathrm{t}}$.

$$
\delta^{15} \mathrm{~N}(\mathrm{t})=-0.0009659 \mathrm{t}^{2}+0.10389 \mathrm{t}+6.61778 ; \mathrm{r}^{2}=0.857
$$

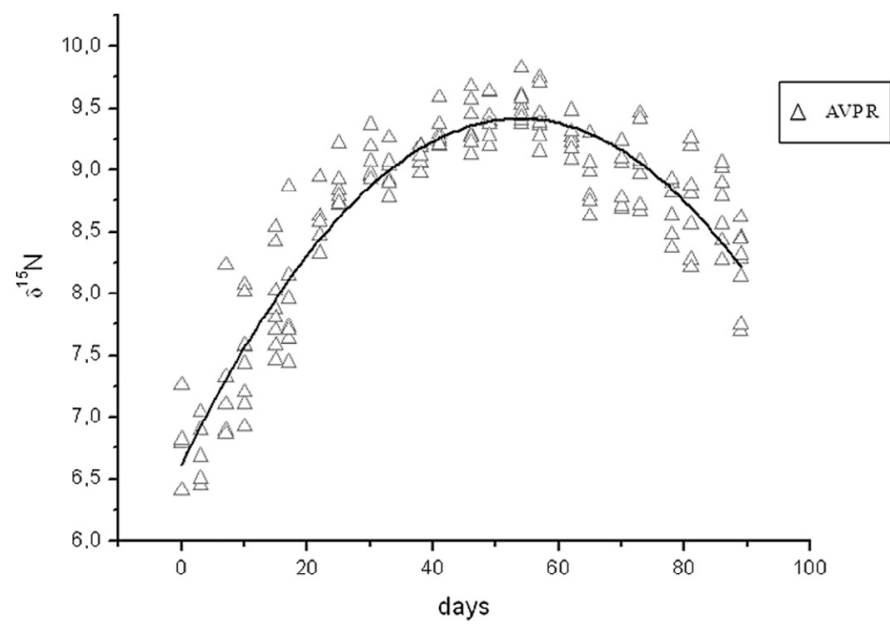

Fig. 2. $\delta^{15} \mathrm{~N}$ values determined from the serum of AVPR sheep, which received $30 \%$ bovine meat and bone meal between days 16 and 49 of the trial, collected at various time points within the trial period. The polynomial curve indicates a maximum of approximately 54 days for the incorporation of animal protein in the serum. 


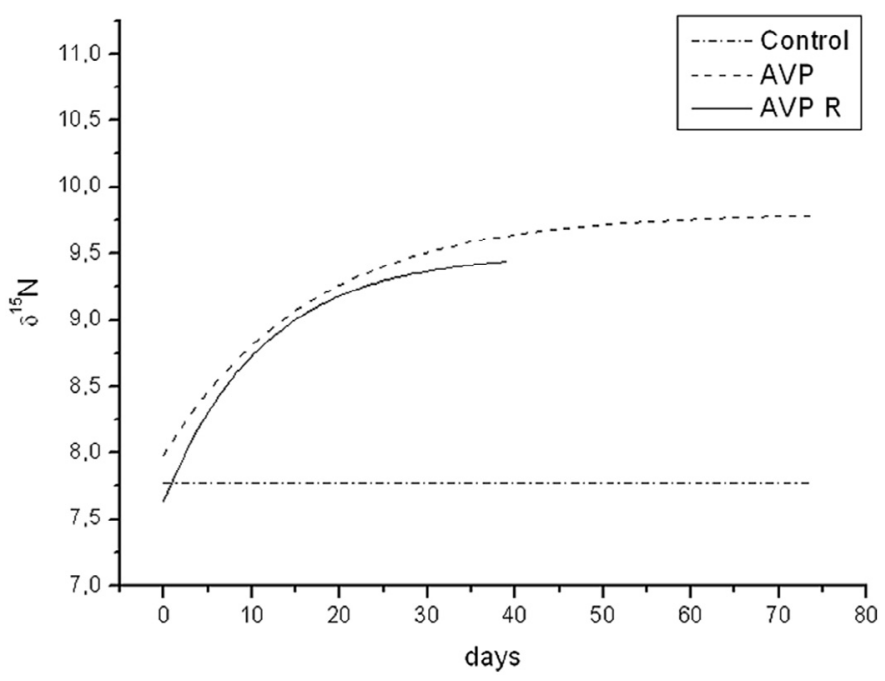

Fig. 3. Exponential fit for the incorporation of ${ }^{15} \mathrm{~N}$ in the serum of sheep from the VP (vegetable protein, control group), AVP (animal and vegetable protein), and AVPR (animal and vegetable protein removal) groups.

Therefore, the estimated time for animal protein elimination in the AVPR group (95\% of exchanged ${ }^{15} \mathrm{~N}$ atoms) was 53 days.

From the analysis of the average $\delta^{13} \mathrm{C}$ and $\delta^{15} \mathrm{~N}$ values $(n=23)$ of the different treatments and periods for the experimental groups it was possible to observe differences from the 22nd day of the experimental dietary treatment, as shown in Table 1. On days 3-15 there were no differences among the treatment groups for the two isotopes.

Based on the dispersion of the $\delta^{13} \mathrm{C}$ and $\delta^{15} \mathrm{~N}$ data for all animals, there were no distinct differences between the experimental groups in the first week of the dietary treatment period (Fig. 5a). However, between days 46 and 54, the control group was quite distinct from the other groups (Fig. 5b). For the last reporting period, days 8189 , the isotopic signals of the control group were similar to those of the AVPR group and were different from those of the AVP group (Fig. 5c).

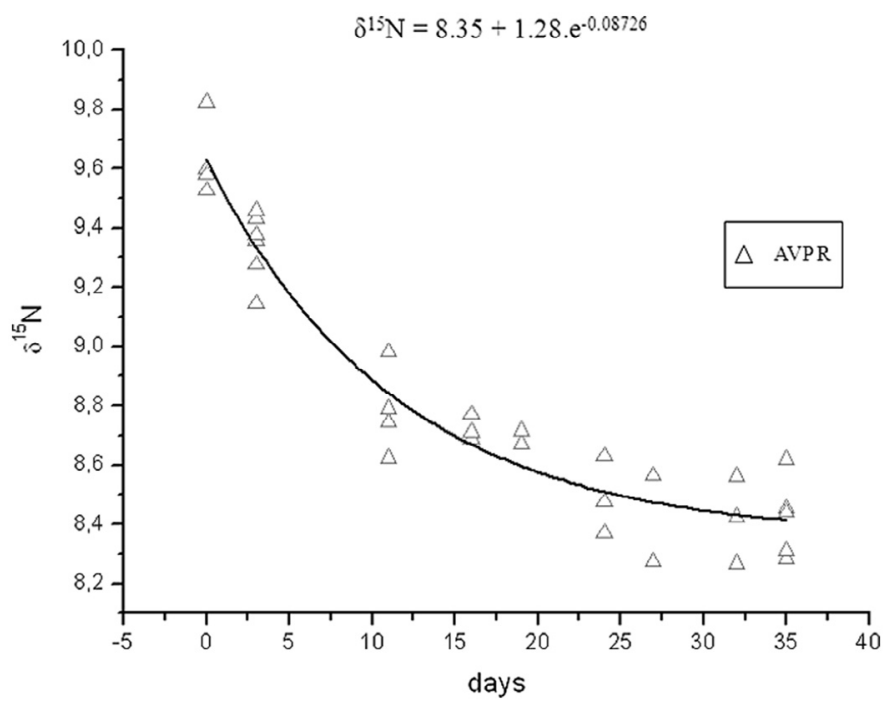

Fig. 4. Exponential fit for ${ }^{15} \mathrm{~N}$ elimination in the serum of sheep in the AVPR (animal and vegetable protein removal) group.
Table 1

Average $\delta^{13} \mathrm{C}$ e $\delta^{15} \mathrm{~N}$ values ( $\left.n=23\right)$ for the different treatments and periods showing changes in isotopic enrichment.

\begin{tabular}{llrr}
\hline Days & Group & $\delta^{13} \mathrm{C}^{\mathrm{a}}$ & $\delta^{15} \mathrm{~N}^{\mathrm{a}}$ \\
\hline 22 & Control & $-14,640 \mathrm{~b}$ & $7989 \mathrm{~b}$ \\
& AVP & $-14,045 \mathrm{a}$ & $8586 \mathrm{a}$ \\
& AVPR & $-14,058 \mathrm{a}$ & $8700 \mathrm{a}$ \\
25 & Control & $-14,398 \mathrm{~b}$ & $7928 \mathrm{~b}$ \\
& AVP & $-14,021 \mathrm{a}$ & $8958 \mathrm{a}$ \\
& AVPR & $-14,172 \mathrm{ab}$ & $8839 \mathrm{a}$ \\
30 & Control & $-14,476 \mathrm{~b}$ & $7800 \mathrm{~b}$ \\
& AVP & $-14,002 \mathrm{a}$ & $9219 \mathrm{a}$ \\
& AVPR & $-14,165 \mathrm{ab}$ & $9061 \mathrm{a}$ \\
65 & Control & $-14,519 \mathrm{~b}$ & $7974 \mathrm{c}$ \\
& AVP & $-13,921 \mathrm{a}$ & $9636 \mathrm{a}$ \\
& AVPR & $-14,224 \mathrm{ab}$ & $8935 \mathrm{~b}$ \\
86 & Control & $-14,444 \mathrm{~b}$ & $8099 \mathrm{c}$ \\
& AVP & $-13,760 \mathrm{a}$ & $10,034 \mathrm{a}$ \\
& AVPR & $-14,317 \mathrm{~b}$ & $8715 \mathrm{~b}$
\end{tabular}

VP, vegetable protein (control group); AVP, animal and vegetable protein group; AVPR, animal and vegetable protein removal group.

a Averages followed by different letters in a column and for every day are significantly different (Tukey's test, $P<0.05$ ).

\section{Discussion}

IRMS analyses of light elements, namely, carbon, hydrogen, oxygen, nitrogen and sulfur (CHONS), provide reliable results about traceability and turnover rates when used to determine the speed of metabolic processes in animals (Manetta and Benedito-Cecilio, 2003; Denadai et al., 2006; Fisk et al., 2009). Using IRMS to trace dietary components can begin at the main power supply as $C_{3}$ plants (e.g., rice, wheat, barley, alfalfa, peanuts, and cotton), with an average isotopic enrichment of $\delta^{13} \mathrm{C}=-28 \%$, and can be distinguished from $\mathrm{C}_{4}$ plants (e.g., sugarcane, corn, and tropical grasses) which have an average value of $\delta^{13} \mathrm{C}=-12 \%$ (Ducatti et al., 2011).

In this study, no change was expected in $\delta^{13} \mathrm{C}$ values as all the experimental diets included the same $C_{3}$ and $C_{4}$ plants, resulting in similar carbon isotope values at each sample collection date.

IRMS and calculations of ${ }^{13} \mathrm{C}$ and ${ }^{15} \mathrm{~N}$ turnover focused on the time periods for the incorporation and elimination of animal protein in sheep serum in response to dietary changes associated with the inclusion of bovine meat and bone meal in the periods prior to the collection of the biological samples. In general, the difference in the ${ }^{15} \mathrm{~N}$ enrichment between the AVP and AVPR groups on the first days after the dietary inclusion of animal protein may be explained by the following hypotheses: first, the adaptation period (0-15 days) might not be sufficient for the equilibration of the isotopic signal, taking into account the original (unknown) diet of the animals; second, the results may be related to animal choice, as the animals exhibited a preference for the Coast-Cross hay rather than the new diet during this period. Further investigations are required to elucidate these findings.

It is well-known that growth rates and rates of weight gain are rapid in sheep (Sarmento et al., 2006), and that turnover and growth rates are correlated. Animals that grow rapidly have higher turnover rates than those that grow more slowly (Manetta and Benedito-Cecilio, 2003). This may partially explain the half-life values of 7.89 and 11.44 days found in the AVPR and AVP groups, respectively, which indicate a fast incorporation of animal protein in the sheep serum. Moreover, the tissues of young animals demonstrate faster turnover rates than those of adult animals (Zazzo et al., 2008; Martinez et al., 2014). For the first time, it has been demonstrated that growth and age play a role in dietary ${ }^{13} \mathrm{C}$ values that are recorded in sheep wool. The wool from fast-growing lambs approaches equilibrium more rapidly than the wool of slow-growing 

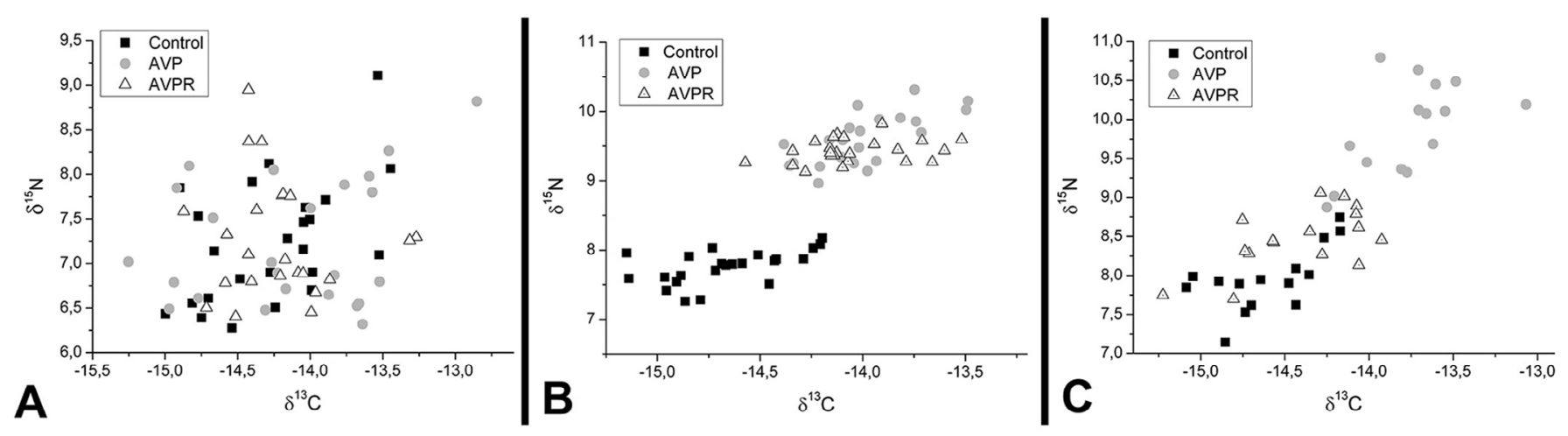

Fig. 5. ${ }^{13} \mathrm{C}$ and ${ }^{15} \mathrm{~N}$ dispersion data for sheep serum samples for the feeding period from (A) 0 to 7 days, (B) 46 to 54 days, and (C) 86 to 89 days.

lambs and young ewes, with old ewes showing the slowest rates (Zazzo et al., 2008). Interestingly, the data here obtained may be supported by these previous findings because this study focused on young sheep.

Our findings could have been affected by tissue type or the biological fluid evaluated because the macromolecular components of cells and tissues undergo a constant process of metabolic renewal (Manetta and Benedito-Cecilio, 2003). Tissues and other bodily components with a high level of metabolic activity or fat (e.g., liver, pancreas, and adipose tissue) exhibit more rapid turnover than less fatty or less active components, such as bone collagen (Hobson and Clark, 1992; Denadai et al., 2006). Metabolic turnover studies on the muscle, liver and blood of captive snakes found that rates were highly dependent on the type of stable isotope, direction of dietary switching (uptake versus elimination), species growth rate, and tissue investigated (Fisk et al., 2009).

Undoubtedly, turnover depends on the absorption, synthesis, and catabolism rates of each tissue component (Denadai et al., 2006). Tissues with fast turnover rates reflect the content of more recent diets, while those with slower rates indicate diets consumed during previous periods (Hobson and Clark, 1992). For example, in bovine skeletal muscles, the turnover of ${ }^{13} \mathrm{C},{ }^{15} \mathrm{~N}$ and ${ }^{34} \mathrm{~S}$ is a slow process; therefore, skeletal muscles contain isotopic information on dietary input integrated over a long period (months to years; Bahar et al., 2009).

The ${ }^{13} \mathrm{C} /{ }^{12} \mathrm{C}$ and ${ }^{34} \mathrm{~S} /{ }^{32} \mathrm{~S}$ ratios in muscles have been found to be the best tracers for beef authentication and for supplying data relevant to animal production practices integrated over the animal's lifetime. Additionally, measuring ${ }^{13} \mathrm{C}$ and ${ }^{15} \mathrm{~N}$ in hair provides a powerful tool for reconstructing changes in the feed components offered to animals over more than a year and thus is useful for verifying farm production practices (Richter et al., 2012). Recently, sheep were evaluated in relation to the results of diet-tissue fractionations for various elements $\left({ }^{13} \mathrm{C},{ }^{15} \mathrm{~N},{ }^{16} \mathrm{O}\right.$ and $\left.{ }^{34} \mathrm{~S}\right)$ and tissues, demonstrating the importance of accurate interpretation of future food authenticity and traceability studies (Harrison et al., 2011). Thus, it is critical to consider the tissue or biological fluid analyzed and whether it constitutes a suitable indicator that can be used to provide relevant data on turnover rates. Therefore, IRMS along with calculations of turnover rates may become more useful depending on the type of biological sample analyzed.

Animal proteins may differ depending on the type of diet the animal was fed. Since $\delta^{13} \mathrm{C}$ values were evaluated and showed no significant variation, it is believed that the diet of the animals from which the protein was obtained was similar to the diet used in the experiment (Martins et al., 2012). $\delta^{15} \mathrm{~N}$ values also indicate the composition of animals' diets, with an enrichment of 2 to 4 per thousand at each trophic level. Therefore, animal protein is enriched in re- lation to the vegetable diet due to the isotopic fractionation associated with catabolic metabolism (Ehleringer et al., 1987). Thus a polynomial fit was used for the data associated with the AVPR diet to determine the maximum enrichment, thereby setting the end time of the initial development and the baseline for the loss of the signal from the animal protein diet.

Mathematical and statistical tools are fundamental in IRMS studies to obtain unbiased results because they depend on data that originate from several chemical elements (CHONS; Sartori et al., 2012). In the present study, the maximum enrichment resulting from the exponential fit provided feasible results about the turnover rates for the AVPR group and showed that the actual time period for incorporation of animal protein in sheep serum was 54 days and not 49 days (the experimental period for dietary removal). Additionally, calculations showed that $97 \%$ of ${ }^{15} \mathrm{~N}$ atoms had been exchanged, confirming the results from the exponential fit. Moreover, serum proved to be an effective biological sample for determining ${ }^{15} \mathrm{~N}$ turnover over the experimental period analyzed.

The estimated time of 53 days for animal protein elimination in the AVPR group ( $95 \%$ of ${ }^{15} \mathrm{~N}$ atoms exchanged) was almost the same as that observed for protein incorporation from the dietary source, indicating that traces of the bovine meat and bone meal are still detectable 53 days after dietary removal, which would require an experimental period of 107 days to fully assess. Hence, the turnover time may reflect a safe and more appropriate time period within which the biological samples should be collected. Finally, turnover has become an attractive tool to verify farm production practices (Osorio et al., 2011) and thus may provide a safe indicator for the consumption of ABPs.

The range of isotopic values found in serum associated with each diet needs to be defined to allow for effective traceability and the detection of ABPs (Mori et al., 2013; Sernagiotto et al., 2013; Madeira et al., 2014). The $\delta^{13} \mathrm{C}$ and $\delta^{15} \mathrm{~N}$ values did not distinguish the experimental groups during the initial period of this study, showing the isotopic similarity of the groups when subjected to the same diet. The period between the 46th and 54th days showed the maximum incorporation of animal protein in the serum, as assessed by calculating turnover. Different responses were observed among the groups, with the isotopic signals in serum samples from the PVA and AVPR groups differing from that of the control animals, demonstrating the ability to track dietary animal protein in the serum.

It should be emphasized that 40 days after the removal of MBM, it was not possible to completely differentiate the response teams; however, the AVPR group signal approached the isotopic signals found for the control group, showing that the dietary detection of animal protein was still possible 40 days after switching to a vegetable diet. 
Our study demonstrated that IRMS is of biological and economical importance for the veterinary field because it can be used to either track intake over a season or assess animal feed intake at a specific time point with a high sensitivity and resolution. IRMS is a relatively low-cost analytical tool and provides fast results.

\section{Conclusions}

Changes in natural ${ }^{15} \mathrm{~N}$ levels were indicative of the incorporation and elimination of animal-derived feed in sheep, whereas ${ }^{13} \mathrm{C}$ levels were not found to change significantly. Measurements of turnover allowed us to evaluate the exchange rate only for nitrogen because the diets used had similar carbon isotope signals. Dietary tracing was possible via the combined analysis of the two isotopes in a scatter diagram despite the small differences found in the analysis of carbon. IRMS analyses of sheep serum allowed the turnover of dietary animal protein to be determined and therefore provided an estimated time period for its incorporation and elimination. Isotopic profiles could be monitored throughout the experimental period, thus demonstrating the possibility of using this method for traceability and certification analyses.

\section{Conflict of interest statement}

None of the authors of this paper has a financial or personal relationship with other people or organisations that could inappropriately influence or bias the content of the paper.

\section{Acknowledgments}

This study was supported, in part, by a grant from the Foundation for Research Support of the State of São Paulo, FAPESP Proc. No. 2012/02689-3 (MRC), Proc. No. 2009/53846-9 (BB and RSFJr), and Proc. No. 2012/08101-8 (RSFJr), CNPq (National Counsel of Technological and Scientific Development) Proc. No. 563582/2010-3 (BB), and CAPES (Coordination for the Improvement of Higher Education Personnel) AUX-PE Toxinology Proc. No. 23038.006285/2011-21 and PNPD No. 23038.008557/2010 (BB). RSFJr is a CNPq DTI fellow researcher (310395/2014-3). Special thanks are also extended to the Center for the Study of Venoms and Venomous Animals (CEVAP) of São Paulo State University - UNESP for enabling the publication of this paper.

\section{References}

Abbade, L.P.F., Barraviera, S.R.C.S., Silvares, M.R.C., Ferreira, R.S., Jr., Carneiro, M.T.R., Medolago, N.B., Barraviera, B., 2015. A new fibrin sealant derived from snake venom candidate to treat chronic venous ulcers. Journal of the American Academy of Dermatology 72, 1-AB271.

Bahar, B., Schmidt, O., Moloney, A.P., Scrimgeour, C.M., Begley, I.S., Monahan, F.., 2008. Seasonal variation in the $\mathrm{C}, \mathrm{N}$ and $\mathrm{S}$ stable isotope composition of retail organic and conventional Irish beef. Food Chemistry 106, 1299-1305.

Bahar, B., Moloney, A.P., Monahan, F.J., Harrison, S.M., Zazzo, A., Scrimgeour, C.M., Begley, I.S., Schmidt, O., 2009. Turnover of carbon, nitrogen, and sulfur in bovine longissimus dorsi and psoas major muscles: Implications for isotopic authentication of meat. Journal of Animal Science 87, 905-913.

Barros, L.C., Ferreira, R.S., Jr., Barraviera, S.R.C.S., Stolf, H.O., Thomazini-Santos, I.A. Mendes-Giannini, M.J.S., Toscano, E., Barraviera, B., 2009. A new fibrin sealant from Crotalus durissus terrificus venom: Applications in medicine. Journal of Toxicology and Environment Health Part B Critical Reviews 12, 553-571.

Bencsik, A., Baron, T., 2011. Histopathological studies of 'CH1641-Like' scrapie sources versus classical scrapie and BSE transmitted to ovine transgenic mice (TgOvPrP4). PLOS ONE 6, e22105.

Bruce, M.E., Will, R.G. Ironside, J.W., McConnell, I., Drummond, D., Suttie, A., McCardle, L., Chree, A., Hope, J., Birkett, C., et al., 1997. Transmissions to mice indicate that 'new variant' CJD is caused by the BSE agent. Nature 389, 498-501.

Cassard, H., Torres, J.M., Lacroux, C., Douet, J.Y., Benestad, S.L., Lantier, F., Lugan, S., Lantier, I., Costes, P., Aron, N., et al., 2014. Evidence for zoonotic potential of ovine scrapie prions. Nature Communications 5, 5821

Cerling, T.E., Ayliffe, L.K., Dearing, M.D., Ehleringer, J.R., Passey, B.H., Podlesak, D.W., Torregrossa, A.M., West, A.G., 2007. Determining biological tissue turnover using stable isotopes: The reaction progress variable. Oecologia 151, 175-189.
Chesson, L.A., Podlesak, D.W., Thompson, A.H., Cerling, T.E., Ehleringer, J.R., 2008 Variation of hydrogen, carbon, nitrogen and oxygen stable isotope ratios in an American diet: Fast food meals. Journal of Agricultural Food Chemistry 56, 4084-4091.

Cosier, V., Daraban, S., 2016. Current understanding of PrnP genetics: A tool for molecular assisted selection in sheep populations (A review). Bulletin UASVM Animal Science and Biotechnologies 73, 11976.

Cruz, V.C., Araújo, P.C., Sartori, J.R., Pezzato, A.C., Denadai, J.C., Polycarpo, G.V., Zanetti, L.H., Ducatti, C., 2012. Poultry offal meal in chicken: Traceability using the technique of carbon $\left({ }^{13} \mathrm{C} /{ }^{12} \mathrm{C}\right)$-and nitrogen $\left({ }^{15} \mathrm{~N} /{ }^{14} \mathrm{~N}\right)$-stable isotopes. Poultry Science 91, 478-486.

Denadai, J.C., Ducatti, C., Pezzato, A.C., Carrijo, A.S., Caldara, F.R., Oliveira, R.P., 2006 Studies on carbon-13 turnover in eggs and blood of commercial layers. Brazilian Journal of Poultry Science 8, 251-256.

Denadai, J.C., Ducatti, C., Sartori, J.R., Pezzato, A.C., Móri, C., Gottmann, R., Mituo M.A.O., Bordinhon, A.M., 2008. The traceability of animal meals in layer diets as detected by stable carbon and nitrogen isotope analyses of eggs. Brazilian Journal of Poultry Science 10, 189-194.

Ducatti, C., Martins, C.L., Arrigoni, M.B., Martins, M.B., Vieira, L.C., Jr., Denadai, J.C. 2011. Use of stable isotopes in ruminants. Brazilian Journal of Animal Science 40, 68-75.

Ehleringer, J.R., Rundel, P.W., Nagy, K.A., 1987. Stable isotopes in physiological ecology and food web research. Trends in Ecology and Evolution 1, 42-45.

Ferreira, R.S., Jr., 2014. Autologous or heterologous fibrin sealant scaffold: Which is the better choice? Journal of Venomous Animals and Toxins Including Tropical Diseases 20, 31.

Fisk, A.T., Sash, K., Maerz, J., Palmer, W., Carroll, J.P., Macneil, M.A., 2009. Metabolic turnover rates of carbon and nitrogen stable isotopes in captive juvenile snakes. Rapid Communication Mass Spectrometry 23, 319-326.

Fossato da Silva, D.A., Biscola, N.P., Souza, R.M.F., Caetano, D.A., Denadai, J.C., Sartori, M.M.P., Silva, E.T., Ducatti, C., Martins, C.L., Jorge, A.M., et al., 2012. Carbon-13 and nitrogen-15 turnover in serum of bubaline donors of biological material for medical use. Toxicon 60, 117.

Harrison, S.M., Schmidt, O., Moloney, A.P., Kelly, S.D., Rossmann, A., Schellenberg, A., Camin, F., Perini, M., Hoogewerff, J., Monahan, F.J., 2011. Tissue turnover in ovine muscles and lipids as recorded by multiple (H, C, O, S) stable isotope ratios. Food Chemistry 124, 291-297.

Hattori, R., Torii, S., Funaba, M., Matsui, T., 2010. Determination of true absorption and fecal endogenous loss of zinc in goats. Animal Science Journal 81, 564-568.

Heaton, K., Kelly, S.D., Hoogewerff, J., Woolfe, M., 2008. Verifying the geographical origin of beef: The application of multi-element isotope and trace element analysis. Food Chemistry 107, 506-515.

Hobson, K.A., 1999. Tracing origins and migration of wildlife using stable isotopes: A review. Oecologia 120, 314-326.

Hobson, K.A., Clark, R.G., 1992. Assessing avian diets using stable isotopes I: Turnover of ${ }^{13} \mathrm{C}$ in tissues. The Condor 94, 181-188.

Houston, F., McCutcheon, S., Goldmann, W., Chong, A., Foster, J., Sisó, S., González, L., Jeffrey, M., Hunter, N., 2008. Prion diseases are efficiently transmitted by blood transfusion in sheep. Blood 112, 4739-4745.

Hunter, N., Foster, J., Chong, A., McCutcheon, S., Parnham, D., Eaton, S., MacKenzie, C., Houston, F., 2002. Transmission of prion diseases by blood transfusion. Journal of General Virology 83, 2897-2905.

Ironside, J.W., 1998. Prion diseases in man. Journal of Pathology 186, 227-234.

Lavonas, E.J., Kokko, J., Schaeffer, T.H., Mlynarchek, S.L., Bogdan, G.M., Dart, R.C., 2011 Short-term outcomes after Fab antivenom therapy for severe crotaline snakebite. Annals of Emergency Medicine 57, 128-137.

Leal, J.S., Andrade, C.P., Correa, G.L.F., Boos, G.S., Bianchi, M.V., Silva, S.C., Lopes, R.F.F., Driemeier, D., 2015. Classical scrapie diagnosis in ARR/ARR sheep in Brazil. Acta Scientiae Veterinariae 43, 69.

Madeira, L.A., Denadai, J.C., Ducatti, C., Pezzato, A.C., Araujo, P.C., Sartori, M.M.P. Pizzolante, C.C., Sartori, J.R., 2014. Assessment of low amounts of meat and bone meal in the diet of laying hens by using stable isotopes. Semina: Ciencias Agrarias 36, 1155-1168.

Manetta, G.I., Benedito-Cecilio, E., 2003. The use of stable isotopes technique in the turnover estimative rate in ecological studies. Acta Scientarium Biological Sciences 25, 121-129.

Marruchella, G., Ligios, C., Di Guardo, G., 2012. Age, scrapie status, PrP genotype and follicular dendritic cells in ovine ileal Peyer's patches. Research Veterinary Science 93, 853-856.

Martinez, M.G., Ducatti, C., Silva, E.T., Sant'Anna, S.S., Sartori, M.M.P., Barraviera, B., 2014. Does the rattle of Crotalus durissus terrificus reveal its dietary history? Journal Venomous Animals and Toxins including Tropical Diseases 20, 53.

Martins, M.B., Ducatti, C., Martins, C.L., Denadai, J.C., Natel, A.S., Souza-Kruliski, C.R., Sartori, M.M.P., 2012. Stable isotopes for determining carbon turnover in sheep feces and blood. Livestock Science 149, 137-142.

Mori, C., Ducatti, C., Pizzolante, C.C., Kakimoto, S.K., Denadai, J.C., 2013. Traceability of animal meals in Japanese quail eggs using the technique of ${ }^{13} \mathrm{Ce}^{15} \mathrm{~N}^{*}$ stable isotopes. Brazilian Journal Poultry Science 15, 59-64.

Osorio, M.T., Moloney, A.P., Schmidt, O., Monahan, F.J., 2011. Beef authentication and retrospective dietary verification using stable isotope ratio analysis of bovine muscle and tail hair. Journal Agricultural Food Chemistry 59, 3295-3305.

Peres, C.M., Bastos, M.F., Ferreira, J., Sartori, A., 2006. Detection and neutralization of venom by ovine antiserum in experimental envenoming by Bothrops jararaca. Journal of Venomous Animals and Toxins including Tropical Diseases 12, 124-136.

Piasentier, E., Valusso, R., Camin, F., Versini, G., 2003. Stable isotope ratio analysis for authentication of lamb meat. Meat Science 64, 239-247. 
Richter, E.K., Spangenberg, J.E., Willems, H., Kreuzer, M., Leiber, F., 2012. Stable carbon isotope composition of perirenal adipose tissue fatty acids from Engadine sheep grazing either mountain or lowland pasture. Journal Animal Science 90, 905-913.

Sarmento, J.L.R., Regazzi, A.J., Sousa, W.H., Torres, R.A., Breda, F.C., Menezes, G.R.O., 2006. Analysis of the growth curve of Santa Ines sheep. Brazilian Journal of Animal Science 35, 435-442.

Sartori, M.M.P., Denadai, J.C., Gracia, A.M.L., Carrijo, A.S., Ducatti, C., 2012. Multivariate analysis of stable isotope data in the traceability process for birds. Acta Scientarum Animal Science 34, 437-442.

Schmidt, O., Quilter, J.M., Bahar, B., Moloney, A.P., Scrimgeour, C.M., Begley, I.S., Monahan, F.J., 2005. Inferring the origin and dietary history of beef from C, N and S stable analysis. Food Chemistry 91, 545-549.

Sernagiotto, E.R., Ducatti, C., Sartori, J.R., Stradiotti, A.C., Maruno, M.K., Araujo, P.C., Carvalho, F.B., Pezzato, A.C., 2013. The use of carbon and nitrogen stable isotopes for the detection of poultry offal meal in meat-type quail feeds. Brazilian Journal Poultry Science 15, 65-70.

Sobrova, P., Ryvolova, M., Adam, V., Kizek, R., 2012. Capillary electromigration based techniques in diagnostics of prion protein caused diseases. Electrophoresis 33, 3644-3652.

Thackray, A.M., Hopkins, L., Lockey, R., Spiropoulos, J., Bujdoso, R., 2011. Emergence of multiple prion strains from single isolates of ovine scrapie. Journal of General Virology 9, 1482-1491.

Tieszen, L.L., Boutton, T.W., Tesdahl, K.G., Slade, N.A., 1983. Fractionation and turnover of stable carbon isotopes in animal tissues: Implications for $\delta^{13} \mathrm{C}$ analysis of diet. Oecologia 57, 32-37.

Zazzo, A., Moloney, A.P., Monahan, F.J., Scrimgeour, C.M., Schmidt, O., 2008. Effect of age and food intake on dietary carbon turnover recorded in sheep wool. Rapid Communication Mass Spectrometry 22, 2937-2945. 